\title{
Recordkeeping and the Management of Prisons in Guyana ${ }^{1}$
}

\author{
Kristy Warren ${ }^{2}$, Dylan Kerrigan, ${ }^{3}$ \\ Keywords: Recordkeeping; Prisons; Guyana; Silences
}

\begin{abstract}
Learning about prison management in Guyana since independence in 1966 is fraught with difficulty due to the paucity of surviving records. This paper investigates attitudes towards and practices of recordkeeping in order to start developing a historical sociology of recordkeeping in Guyana. Within this framework, prison recordkeeping is explored for the colonial and postindependence periods. The paper ends with a consideration of other sources and methods that are needed to provide a fuller picture of both prison management and the experiences had in prison by prisoners and prison officers.
\end{abstract}

\section{Introduction}

Recordkeeping is as an important factor of governance as it helps to ensure transparency and accountability (Dikopoulou and Mihiotis 2012, Lowry 2014). However, within the Anglophone Caribbean context, recordkeeping in government-run prisons and its meaning for both prisoners and prison staff has received little attention. This working paper opens by outlining the post-independence historical sociology of recordkeeping in Guyana. This allows for a more comprehensive understanding of the challenges faced due to insufficient resources and the low status of and lack of awareness that often surrounds the keeping and use of government records in ex-colonies (Prasad 1972, Payne 2018). We then consider the present state of recordkeeping in the Guyana Prison Service (GPS) in particular, how a lack available knowledge can impact upon what can be learned about local prisons in the post-independence era. Finally, by way of recommendations, we consider what additional resources can be used to address the silences created by an absence of critical records covering this period.

\section{The sociology of absences}

There is a distinct connection between records which are kept, those which are lost, and how we come to understand the past. Surviving records provide part of the evidence used to write and talk about what has passed. But the existence of records is only part of this story. Of additional importance is whether records can be accessed by policymakers, government officials, historians, and concerned citizens. Silence and absences thus exist at different stages in the production of history. This has been noted by Michel-Rolph Trouillot $(1995, \mathrm{p} 26)$ who observed that silencing occurs at four stages: at the moment of creation; during the process of what is preserved and what is destroyed; how the actual information is retrieved from the

\footnotetext{
1 This paper is based on research conducted for the ESRC-funded project Mental Health, Neurological and Substance Abuse (MNS) Disorders in Guyana's Jails: 1825 to the present day (award no. ES/S000569/1). This project is a collaboration between the University of Guyana and the University of Leicester, in partnership with the Guyana Prison Service. The project brings into dialogue, researchers in History, Criminology, Sociology and Literature. It takes both a multi-disciplinary and interdisciplinary approach to key questions about the form, function, and experience of incarceration, encompassing inmates and the people who work with them. It encompasses both the British colonial period, and the era since Guyana's independence in 1966.

${ }^{2}$ Research Associate, School of History, Politics and International Relations, University of Leicester, Leicester, UK. Email: kw272@le.ac.uk. ORCID: 0000-0001-6790-4010.

${ }^{3}$ Lecturer, Department of Criminology, University of Leicester, Leicester, UK. Email: dk252@1e.ac.uk. ORCID: 0000-0003-2453-9804.
} 
documents and finally when history is written. Herewe begin by focusing on the second and third stages, as these are most relevant to the consideration of recordkeeping itself.

In contemplating how and why documents are preserved, and the extent to which they are organised in a way that makes them usable, it is useful to consider Barbara L. Craig's call for an 'historical sociology of the record' (1992, p 121). Following on from Craig, Michael Piggot (1998, p 350) explained what an historical sociology of recordkeeping might consist of: "[p]art at least will be how ... society and its constituting groupings and strata have been ordered and governed by record-keeping." One aspect of the sociology of record-keeping can therefore be said to be concerned with understanding how those who create and use records is central to institutional governance (Piggot 1998, p 354).

Understanding recordkeeping within a Caribbean context can help illuminate how silences in the records have emerged not only from conscious decisions about what to keep and what to destroy, but also in many cases, through neglect to institute good recordkeeping systems in the development of different polities. Victoria Lemieux argues that regional aims for good governance require good recordkeeping. Yet, Lemieux (2018, p 240) argues, "for many governments, records management is a low priority." She further notes that this is often due to a lack of resources, which leads to decisions about what needs immediate attention and what can wait. Considering this neglect also necessitates understanding that Caribbean state institutions "face a range of issues that are deeply rooted in their shared culture and colonial past” (Lemieux 2018, p 237-38).

It is also worth recognising here, another silence around the relationship and relationality between transhistorical social structure and institutional development in the Caribbean - and that without recognition of the colonial structures and hierarchies laid down by colonialism and Empire, it is difficult to understand the development of post-colonial Caribbean institutions and governance. This includes questions of materiality - in particular those pertaining to political economy and a lack of funding for record-keeping - within Caribbean independence movements (Getachew 2019). In this sense, post-colonialism in the Caribbean might be said to have carried within it the seeds of de-materiality - because in building the needed systems and structures of governance for post-independence, there was no structural redistribution of funds, or reparations from former colonial powers. This in turn left holes in the ability of post-colonial governments to finance the institutional systems needed for good governance.

\section{General history of recordkeeping}

The conflict between aims and what is actually done can be traced back to the 1960s as many British colonies in the Caribbean began moving towards independence. In September 1965 the first Caribbean Archives Conference was held in Jamaica; it attracted attendees from across the region including P. P. Dial, the Government Archivist of British Guiana (Report of the Caribbean Archives Conference 1965, p 36). Alongside the push to collect papers relevant to the past, those gathered at the conference also wanted to develop a system for collecting current records that would be used by future historians. Much was accomplished across the region concerning the development of archives, and archival and recordkeeping training thanks to the University of the West Indies (UWI), Caribbean Regional Branch of the International Council on Archives (CARBICA), and other archival organisations. However, limited resources were sometimes accompanied by a compromised form of political will that was - for a variety of reasons - compounded by the realities of post-colonial Independence. This included ethnic politics and creole nationalism which impacted effective forms of bureaucracy and sought to 
maintain many of the social class hierarchies of colonialism (Hintzen 2004, p 107; Brown 1999, $\mathrm{p}$ 368). These structural impediments and other factors meant some of the goals set out during this conference remained unachieved. Thislaid the ground for future absences and silences in the records.

A survey conducted in the 1990s by CARBICA showed that ten countries in the region had "formal records and information management programmes", among them was Guyana. However, "only seven of these countries had integrated programmes covering all or most government records", and Guyana was not one of them (Aarons and Alexander-Gooding 2018, $\mathrm{p}$ 35). Thus, the different methods used to organise records held by individual government departments and ministries has made the sharing of records difficult.

Although there is little written about recordkeeping in Guyana, the experience of those working in the country's archives gives some insight into the value - or lack thereof - placed on maintaining government records. Former Government Archivist of Guyana, Hugh 'Tommy' Payne (2018, p 123) explains that "low status has been traditionally accorded to National Archives agency in the Caribbean." Reflecting on his time as Archivist, Payne (2018, pp 118 and 120) notes that the Archives Department was held in 'low esteem' with archival workers moving on to more prestigious and better paid appointments within the Civil Service. The Archives also worked with a limited budget. The low status and insufficient budget assigned to the Guyana Archives,and what this meant for the work of the Archivist,was reflected upon by Indian historian, the then Director of the National Archives of India, Sri Nandan Prasad (1972, p 6 in Payne (2018, p 118)):

With an annual budget of only about fifteen hundred US dollars (apart from salaries of the nine employees of the archives) improvisations and the cheapest of solutions of problems are obviously imperative for the Guyana archivist ... In Guyana, the administrators and the intelligentsia have yet to appreciate the importance and value of archives...

Indeed, these issues concerning recordkeeping have ramifications in the present day as can be seen in a comment piece subtitled: 'Guyana's record-keeping leaves much to be desired' by Editor in Chief of Kaieteur News, Adam Harris (2019). Harris (2019) states, "Guyana has never set much store in archiving material." He reviews the impact of missing records through examples including his inability to source his employment records and the Guyanese Government's request for copies of documents from the Netherlands to support its case in a border dispute with Suriname.

\section{Discussion Point One: History of prison recordkeeping in Guyana}

Issues concerning recordkeeping that impact the way that prison records are collected and organised in Guyana are part of a wider geographical and historical concern which encompasses the (mostly) former British Caribbean and draws on practices enacted elsewhere - primarily the United Kingdom and the United States. Prison records also fit within Guyanese Government recordkeeping policies and practices. Placing current concerns about recordkeeping within this wider framework allows for a better understanding of the advantages and pitfalls of past, current and projected systems.

Payne (n.d.) wrote a report on the history of prisons in Guyana which provided information about penal confinement in the colony from the seventeenth century. The report is not dated, but as Payne began working for the Archives in late 1965 (Payne, 2018, p 116), this 
piece of work appears to have been written in the early days of independence. ${ }^{4}$ It is not clear who commissioned the report, but its existence shows a desire by someone - most likely a government official - to understand the history of prisons during the colonial era. This can be situated within wider Caribbean aims to gather historical records at a time when most of the colonies were moving towards independence (Robinson, 2018).

The brief report shows the importance of existing prison records, and what they can reveal about past administrative decisions, to the continued management of such institutions whether that is to continue organising along the same lines or to find points of departure. It tells us about the limits imposed by the silences created by missing records. Payne (n.d.) begins with the Dutch settlement period and notes the lack of information about early prisons. He explains that this limits what he can focus on for this early period as the information concerning the first prison appeared "to be among a valuable but vanished set of documents" (Payne n.d., p 1).

In the absence of primary sources for this period, Payne (n.d) draws primarily on two texts, by A R F Webber and Henry G. Dalton, which cover the general history of British Guiana and its Dutch predecessors. He surmises that there were most likely no prisons at first as the records that are available show that the common punishments during that period involved banishment and execution rather than imprisonment. He suggests that the former was used for both enslaved and free people and the latter for the enslaved alone. Additionally, although the colony lacked prisons, lock-ups on individual plantations were used to punish the enslaved.

The sources available shifted during British colonisation. We know what most of these sources are because copies were sent back to the Colonial Office in London and remain in the National Archives at Kew and other UK repositories. But what remained in the archives in Guyana? Payne (n.d.) draws on reports and commissions written from 1873 to explore continuity and change in prison administration. Although he does not refer directly to annual reports, he notes that he had planned to include statistics in the report but did not do so due to time constraints; suggestingthat he had access to these reports.

The question of the impact of Payne's report was also remains. Many reports are written to facilitate change, but are shelved and forgotten. Thus, the issue is not just with the creation of records, but how records are organised and then used. Not least it is worth considering how records become tools in the context of political expediencies and State capture and the production of top-down narratives around social control and good governance.

\section{Discussion Point Two: present day prison records}

As previously mentioned, recordkeeping and archival practice in Guyana has been impacted by a range of factors including a lack of resources, interest and knowledge about its value by those who can effect the greatest change (Payne 2018; Hintzen 2004; Brown 1999). This does not mean there is a total lack of interest, rather that there has been little effort until recently to take a unified approach. As a result, both the post-independence archive and more recent records about prisons in Guyana are scattered and fragmented. For instance, Payne's Prison Report was found not in a government collection but in the Caribbean Research Library (CRL) at the University of Guyana. ${ }^{5}$ A number of government-produced reports, including Prison and Police Annual Returns, were located in this collection.

\footnotetext{
${ }^{4}$ Payne was an Inspecting Officer in the Guyana Archives when this was written. He took up this post in 1965 and was made Archivist in May of 1970.

${ }^{5}$ Although it is possible that other copies are held in government repositories.
} 
For late twentieth and twenty first century records, it has been necessary to piece together a series of documents across government departments; for example,the annual Prison Returns. These are records which give us an overview of the administration of the prison. Due, in part, to a fire which occurred at Georgetown Prison in July 2017, where the bulk of the records was stored, the Prison Service does not have a complete set. Only five were found to be held by GPS. The Prison Service sits within the Ministry of Public Security, but the Ministry hold only six Annual Reports;five of which were also found at the National Archives of Guyana. In addition to Payne's report, the University Library also has four Annual Reports. A further two Annual Reports were found at the Parliamentary Library. Reports for a couple of years were found in more than one place. Working across these four sites, it was possible to assemble seventeen Prison Annual Reports from between 1977 and 2017 (some of which are drafts). That means for a forty-year period, less than half of the Annual Reports that would have been produced have been found so far. It is possible that additional records are held in the private collections of former employees; this is something we plan to investigate.

Of course, there are also other records that we can use to gain information about prisons and prisoners that were produced by the GPS, other government departments, and regional and global organisations. These include paper records held at each prison site concerning prisoners; Police Annual Reports - which give some information about conviction rates; as well as UK Foreign and Commonwealth Office (FCO) Country Reports on Human Rights, and US Department of State reports, which both give information about conditions in Guyanese prisons. Many of these records are also limited and/or difficult to access, with the most accessible being produced in the twenty first century. Some of the earlier documents may be held in repositories that have yet to be checked for the post-independence period, such as the UK National Archives. Regardless, it would not be surprising if the percentage of remaining documents is small.

As noted earlier, the lack of historical records does not reflect a current disinterest in documentation by those who need the information to manage the prisons or make wider policies concerning security in Guyana. Far from it. Prior to the MNS project, the GPS was partners in a British Academy funded project led by Clare Anderson concerning the history of Guyanese prisons. Materials from that project were compiled by researcher Kellie Moss who explained that they were presented to the Minister of Public Security in November of 2019. Hundreds of copies were provided to the GPS to be used for public information and presentations.

Additionally, those we spoke to currently working within the GPS and the Ministry of Public Security knew the value of the records and were eager to work with the MNS Guyana project to gain copies of the reports they did not hold. Staff at the Ministry noted the importance of such records for underpinning evidence-based policymaking.

Consistent prison records are needed as they form part of wider aims of good governance but also because they offer protection to prisoners by providing evidence of the conditions of prisons and what is needed to improve them. They can show how things have or have not changed over time and how this has impacted prisoners and wider society. Such evidence is needed for the creation of better policy. But we also argue that other forms of evidence that provide information offered by a range of voices about the experiences of the imprisoned are also needed if we are to truly comprehend the impact of imprisonment. These include the interviews we are doing with prisoners and prison staff; Commissions of Enquiry 
concerning prison conditions which have been held at various intervals; writings by former prison officers, and the observations of those who have been incarcerated.

\section{Conclusion}

Developing an historical sociology of recordkeeping in Guyana allows us to build on existing social histories (Payne n.d.), as well as those found in national newspapers which provide both summaries of missing records such as annual reports along with observations about prison life provided by former prison officers and prisoners. These sources can be used alongside official documents such as commissions of enquiry and available annual and monthly reports to provide a fuller picture. It is therefore necessary to question information that has already been collected, the history of this collection and what is needed going forward in order to ensure good recordkeeping practice to provide the required evidence concerning the management of prisons and the experiences of the incarcerated and those who work there.

It is also necessary to consider what is missing. This includes both understanding which official records are no longer available, but also the kinds of information that are not found in those records. Necessary then, is exploring alternative archives and conducting interviews with prisoners and prison officers. Working with such a broad range of sources in the context of speaking to the silences and absences of Guyanese prison records would place this work within the wider explorations of the Guyanese and Caribbean past undertaken by numourous researchers, writers and practitioners who have faced the silence of the official record before us.

\section{References}

Aarons, John A. and Alexander-Gooding, Sharon (2018) Historical Developments in Caribbean Archives and Record Keeping, in Bastian, Jeannette et al. eds., Decolonizing the Caribbean Record: An Archives Reader, Sacramento: Litwin Books.

Brown, Deryck R., (1999)Ethnic politics and public sector management in Trinidad and Guyana. Public Administration and Development, 19:4, 367-379.

Caribbean Archives Conference (University of the West Indies) (1965), Report of the Caribbean Archives Conference Held at the University of the West Indies, Mona, Jamaica, September 20-2, 1965, UWI and the Government of Jamaica.

CARICOM (2016) "Strategic Plan for the Caribbean Community 2015-2019: Repositioning CARICOM, Vol. 1: The Execution Plan," as cited in Lemieux, Victoria L. (2018) Recordkeeping, Strategic Priorities, and Governance in Small Island Caribbean Communities, in Bastian, Jeannette et al. eds., Decolonizing the Caribbean Record: An Archives Reader, Sacramento: Litwin Books.

Craig, Barbara L. (1992) 'Outward visions, inward glance: archives history and professional identity, Archival Issues, vol. 17 no. 2, as found in Piggot, Michael (1998) 'The history of Australian record-keeping: a framework for research, The Australian Library Journal, 47:4, 343-354.

Dikopoulou and Mihiotis (2012) The contribution of records management to good governance, The TQM Journal, 24:2, 123-141. 
Princeton: Princeton University Press; Burden-Stelly, Charisse and Percy C. Hintzen, (2016). "Culturalism, Development, and the Crisis of Socialist Transformation: Identity, the State, and National Formation in Thomas's Theory of Dependence", The CLR James Journal 22, 1-2 (Fall 2016), 191-213.

Harris, Adam (2019) My Column: Guyana's record-keeping leaves much to be desired, Kaieteur News, 31 March, available from: https://www.kaieteurnewsonline.com/2019/03/31/guyanas-record-keeping-leaves-much-tobe-desired/, accessed 14 January 2020.

Hintzen, Percy C., (2004) Creoleness and nationalism in Guyanese anticolonialism and postcolonial formation. Small Axe, 8:1, 106-122.

Lemieux, Victoria L. (2018) Recordkeeping, Strategic Priorities, and Governance in Small Island Caribbean Communities, in Bastian, Jeannette et al. eds., Decolonizing the Caribbean Record: An Archives Reader, Sacramento: Litwin Books.

Lowry, James (2014) Record-keeping for Good Governance and Accountability in the Colonial Office, in Lowry James and Justus Wamukoya eds., Integrity in Government through Records Management: Essays in Honour of Anne Thurston, London: Routledge.

Payne, Hugh 'Tommy' n.d. [after 1965] 'Report on Prisons,' Caribbean Research Library, University of Guyana.

Payne, Hugh W. L. (1981) Oral History and Non-Documentary Sources, Proceedings of the Third Caribbean Archives Conference, Nassau Bahamas, 22-26 October 1979.

Payne, Hugh 'Tommy' (2018) Working at the National Archives of Guyana: Experiences, Challenges \& Lessons, in Bastian, Jeannette et al. eds., Decolonizing the Caribbean Record: An Archives Reader, Sacramento: Litwin Books.

Piggot, Michael (1998) 'The history of Australian record-keeping: a framework for research', The Australian Library Journal, 47:4, 343-354.

Prasad, Sri Nandan (1972) 'Viewpoint of Archivists from Developing Countries on Archival Development,' VII International Congress on Archives, Moscow as cited in Payne, Hugh 'Tommy' (2018) Working at the National Archives of Guyana: Experiences, Challenges \& Lessons, in Bastian, Jeannette et al. eds., Decolonizing the Caribbean Record: An Archives Reader, Sacramento: Litwin Books.

Robertson, James (2018) Making the West Indian Archive Accessible, in Bastian et al. eds, Decolonizing the Caribbean Record, Sacramento: Litwin Books.

Trouillot, Michel-Rolph (1995) Silencing the Past, Boston: Beacon Press. 